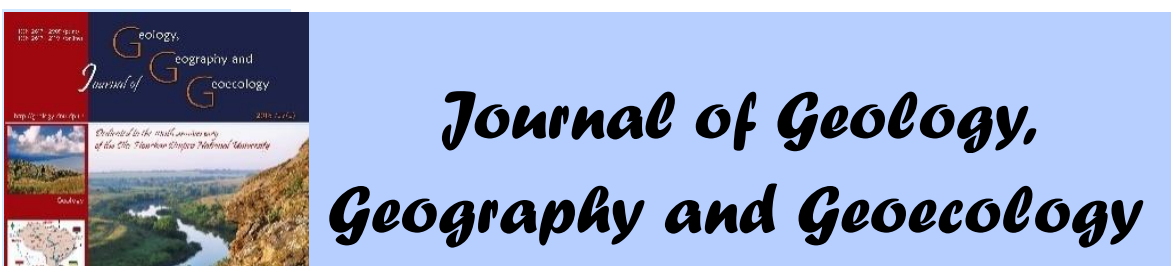

Journal home page: geology-dnu-dp.ua

Journ.Geol.Geograph. Geoecology, 28(1), 59-67 doi: $10.15421 / 111907$
Journ.Geol.Geograph.Geoecology, 28(1), 59-67

\title{
Labour migration of the population of Ukraine to the countries of the European Union: factors and risks of influence
}

\author{
N.F. Habchak ${ }^{1}$, L.F. Dubis ${ }^{2,3}$
}

\begin{abstract}
${ }^{1}$ State Higher Educational Institution «Uzhhorod National University», Uzhhorod, Ukraine e-mail: Habchak.nf@gmail.com

${ }^{2}$ The John Paul II Catholic University of Lublin, The Faculty of Mathematics, Informatics and Landscape, Department of Landscape Ecology, 1 H, Konstantynów Street, Lublin, 20708, Poland

${ }^{3}$ Ivan Franko National University of Lviv, Faculty of Geography, Chair of Geomorphology, 41, Doroshenka Street, Lviv, 79000, Ukraine e-mail: lida.dubis@gmail.com
\end{abstract}

Received 13.02.2019;

Received in revised form 20.02.2019;
Accepted 06.03.2019

Abstract. Nowadays the migration of the population plays an important role in the development of a country, a region, a town and it is the result of socio-economic changes. The population of Ukraine and its regions is decreasing in recent years due to three main reasons: 1) the demographic crisis; 2) the activation of migration processes; 3) the military conflict in the east of the country. If the demographic component is a natural process that is covering European countries more than one year, then the others point out a lot of unfavorable factors that has been formed inside Ukraine and «push» the population into the international migration processes.

The problem of labour migration is complex, systematic and its solution must be based on the improvement of socioeconomic policies of the country or region. Migration processes at the world-wide European and Ukrainian levels are investigated by such domestic scientists as O.A. Malynovska, Y.M. Pakhomov, A.O. Nadtochiy, D.V. Chekushyna, S.O. Zapadnyuk, V.P. Miklovoda, M.I. Pityulych, N.A. Syrochuk, V.S. Morokhovych and others. In the structure of migration flows of Ukraine foreign labour migration takes the first place, which has acquired a large-scale nature and has absorbed a significant number of economically active population of the country at the age of 20-34 years over the past 10 years. In particular, in 2016 the number of men who left Ukraine at the age of 20-24 was 3897 people; at the age of 25-29 years - 2360 people, at the age of 30-34 - 1086 people. As for women, their number varies in two age categories: 20-24 years old - 1487 people and 25-29 years old - 1226 people. The dynamics of the migration movement of the population in the regions of Ukraine is divided into four regions of Ukraine, which are «the leaders» according to the number of those who went abroad, namely: Dnipro region (2300 people), Transcarpathian region (1519 people), Odesa region (2126 people) and Kharkiv region (3291 people). According to the State Statistics Committee in Ukraine there are 16 million economically active citizens, 12.8 million of them officially work. Taking these numbers into consideration, the problems with the pension system will arise first and foremost. Nowadays 10 working Ukrainians account for 15 pensioners. If the pace of migration remains, then the ratio will change to 8 for 15. Analysts warn that according to the outflow of labour resources, Ukraine is losing about 40 billion UAH annually. Moreover, the shortage of workforce is putting back the development of some sectors of industry, agriculture, hospitality industry and leads to the decline of regions. It should be noted that unemployment is a major factor in the activation of labour migration in researches. The decline of the Ukrainian economy increased the unemployment level of the population. Although the pace of recovery of economic activity shows a positive dynamics, we have not succeeded yet in reaching the employment level of at least the pre-crisis period. The main reason for the unemployment increase was the fall of the economy and the corresponding decline in finances of enterprises. An analysis of the unemployment rate shows a significant disproportion in employment in the regions of Ukraine in January 2017. We distinguish such reasons: 1) different socio-economic level of development of regions; 2) lack of jobs; 3) political instability; 4) military actions in the east of the country. The best employment situation is observed in Kharkiv, Kyiv, Odesa, Lviv, Dnipro regions and the worst - in Luhansk, Donetsk, Volyn, Ternopil and Kirovograd regions. These important arguments prove the inevitability of the intensification of labour migration flows into the countries of the European Union and the European vector of labour migration for Ukrainians remains crucial not only today but also in the long run. The dynamics of labour migration from Ukraine is as follows: in 2008 the number of labour migrants from our country reached 1.2 million people and according to the ranking Russia, Italy, Czech Republic, Poland and Hungary were chosen; in 2012 the number of migrant workers has not changed (1.2 million), but the vectors of the countries, that migrants chose, have changed - Russia, Poland, Italy, the Czech Republic, Spain; in comparison with previous years in 2017 the number of migrant workers increased to 1.3 million people who settled in Poland, Russia, Italy, the Czech Republic and the USA. There is a slightly different spatial picture of the migrants' movement of Ukraine directly with the countries that it borders. We witness an abrupt increase in the numbers from 2012 till 2017 in Poland (up to 10 million people), in Hungary (up to 3 million people), Romania and Slovakia (1.5 million people). The departure of Ukrainian citizens to Russia has decreased, in particular, in 2013 the number was the largest and reached more than 6 million people. In the next period of 2014-2016, due to military actions in eastern Ukraine, the number decreased to 4 million people and only in 2017 began to increase to 5 million people again. It should be noted that $60 \%$ of 
them are labour migrants. The situation that has appeared in the field of labour migration requires the government of the country to take steps in regulating labour migration at the legislative level and to implement a number of measures, as follows:

- the protection of the rights of labour migrants, the legalization of their employment;

- the development of special regional programs for stimulating self-employment of those migrants who have returned from abroad after labour migration;

- the assistance from public authorities in launching businesses, small businesses, farming by the labourers who returned;

- to give them the opportunity to take refresher courses and retraining in different fields, etc.

Thus, the analysis of new trends in labour migration both in Ukraine and in Transcarpathian region requires the intensification of the international cooperation with the member countries of the European Union in creating favorable conditions for the legalization of Ukrainian labour migrants, cooperation in the field of border control, the promotion of reverse migration, the raising the socio-economic standard of living in Ukraine, because the risks of labour migration are assessed as alarming.

Keywords: labour migration, migration flows, demographic policy, economic crisis, economically active population, migration policy.

\title{
Трудова міграція населення України до країн Свропейського Союзу: чинники та ризики впливу
}

\author{
Н.Ф. Габчак ${ }^{1}$, Л.Ф. Дубіс ${ }^{2,3}$ \\ ${ }^{1}$ ДВНЗ «Ужсгородський наџіональний університет», м. Ужсгород, Україна, e-mail:Habchak.nf@gmail.com \\ 2.Люблінський католицький університет Івана Павла II, фракультет Математики, Інформатики $i$ \\ Архітектури Ландшафту, Люблін, Польща \\ 3.Львівський національний університет імені Івана Франка, географічний факультет, Львів, Украӥна, е- \\ mail: lida.dubis@gmail.com
}

\begin{abstract}
Анотація. Стаття присвячена дослідженню питань зовнішньої трудової міграції населення України. Визначено основні причини зростання міграційних потоків з метою працевлаштування. Коротко проаналізовано науковий доробок вітчизняних вчених з даної проблематики. Розглянуто вплив міграцій на темпи соціально-економічного розвитку країни, регіону. Охарактеризовано демографічну ситуацію в країнах ЄС та СНД, функціонування їх національного ринку праці, проблеми та ризики міграційного руху економічно активного населення на рівні регіонів. Розкрито суть головного чинника, що «виштовхує» трудових мігрантів 3 країн це - безробіття. Наведено, як приклад, області України 3 найнижчими та найвищими показниками зайнятості населення. Виокремлено вектори трудової міграції, їх часові зміни та особливості. На основі аналізу статистичних даних виокремлено «західні» та «східні» вектори трудоміграційних потоків українців та охарактеризовано їх основні риси. Створено ряд рисунків, які дозволяють зробити аналіз тих чинників, які $\epsilon$ визначальними у формуванні міграційних процесів. Подано просторову картину руху трудових мігрантів України безпосередньо 3 країнами-сусідами по суходолу. Доведено різке зростання їхньої кількості в період з 2012 - 2017 рр. в Польщі (до 10 млн. осіб), Угорщині (до 3 млн. осіб), Румунії та Словаччині (1,5 млн. осіб). Зменшення виїзду громадян України до Росії, зокрема, у 2013 році їх кількість була найбільшою і становила більше як 6 млн. осіб. В наступний період 2014-2016 рр. у зв'язку з воєнними діями на сході України їх кількість зменшилась до 4 млн. осіб і тільки в 2017 році знову почала зростати до 5 млн. осіб. 60\% з них $є$ саме трудовими мігрантами. Визначено пріоритети державної політики України щодо врегулювання трудової міграції на законодавчому рівні та запропоновано цілий ряд заходів захисту прав трудових мігрантів, легалізацію їх працевлаштування, розробку спеціальних програм стимулювання самозайнятості тих мігрантів, які повернулись додому. Розроблено пропозиції щодо зменшення ризиків трудової міграції на території дослідження.
\end{abstract}

Ключові слова: трудові міграчії, міграчійні потоки, демографічна політика, економічна криза, економічно-активне населення, міграційна політика.

Introduction. In modern conditions migration of population plays an important role in the development of a country, a region or a settlement and is a consequence of social and economic changes. The population of Ukraine and Transcarpathian region in particular, has been decreasing over recent years due to three main reasons: 1) the demographic crisis, 2) the intensification of migration processes and 3) the military conflict in the eastern part of the country. The demographic component is a natural process that has influenced European countries for many years, the other ones indicate a number of unfavourable factors that have been formed inside
Ukraine and «push out» its population into international migration processes.

According to experts under such conditions there is a threat of even greater intensification of emigration processes that are associated with the outflow of labour outside the borders of Ukraine and its administrative and territorial unit Transcarpathian region.

Obviously, the problem of labour migration is a complex and has systemic nature and its solution should be based on the improving of the socio-economic policy of the country or region.

Materials and research methods. In the process of research the following methodical tools were used: methods of analysis and synthesis, 
observation, historical, cartographic methods, statistical and comparative analysis as well.

Results and analysis. The migration processes at the global European and Ukrainian levels have been investigated by the domestic scientists, in particular: O.A. Malynovska, Yu.M. Pakhomov, A.O. Nadtochiy, D.V. Chekushyna, S.O. Zapadniuk, V.P. Miklovda, M.I. Pitiulych, N.A. Syrochuk, V.S. Morokhovych and others.

It should be noted that these scholars study the issues of evaluation and analysis of the main factors of the external labour migration. Thus, Yu.V. Chekushyna investigates the issues of internal and external intellectual migration of population in modern Ukraine; V.S. Morokhovych analyzes the dynamics of the migratory movement of the population in Transcarpathian region; O.V. Havrylets describes the main relationships between the factors characterizing the social and economic situation of the region and the indicators of external migration. V.P. Miklovoda and M.I. Pitiulych reveal new trends in the labour and migration processes of the economically active population in Transcarpathian region.

We have conducted a study of the external labor migration processes, identified the reasons of their activation in the period of 5-10 years within Ukraine and cross-border areas of the Transcarpathian region and the European countries (EU).

Migration movements require constant monitoring and analysis of their impact on the pace of social and economic development of the country. It means the research topic is of great importance nowadays (Nadtochii, 2015).

According to O.M. Lyashenko and Yu.I. Champagniuk migration of the population in the XXI century is the leading form of the international relations in the world. During different periods of the history of mankind, it was distinguished by various scales and directions, as well as in forms and types.

The 90s had their own signs of labour migration, which was expressed in the form of mass trips of the Ukrainians, especially from the crossborder territories to the neighbouring countries for cheap commodities. At the turn of the millennium, we single out a new stage of going to work abroad, which is associated not only with the aggravation of the economic crisis, unemployment, underemployment or lack of demand for the profession, but also with the military actions in the ATO zone in the Eastern part of Ukraine.

In the structure of migration flows of Ukraine the leading place is taken by the external labour migration, which has acquired a large-scale character over the past 10 years and has involved a large number of economically active population of the country aged from 20 to 34 . In particular, in 2016 the number of men who left Ukraine at the age of 20-24 was 3897; at the age of 25-29 - 2360 men, and 1086 men - at the age 30-34. As for women, the number varies in two age categories: 1487 women left Ukraine at the age of 20-24 and at the age of 25-29 the number was 1226. The dynamics of the migration movement of the population in the regions of Ukraine is shown in Table 1 which identifies four regions of Ukraine that are the 'leaders' by the number of 'those who went' abroad, namely: Dnipropetrovsk region (2300 people), Transcarpathian region (1519 people), Odesa region (2126 people) and Kharkiv (3291 people).

It should be noted that the unfavourable demographic situation in the EU and CIS countries with the tendency to depopulate the population causes a problem concerning the quality of the national labour market functioning, as well as the demand for employees in these regions. If in the 1990s every fourth person in the world was a European. According to UN experts, by 2050 the proportion of Europeans will decrease from 10 to $7.2 \%$, and the share of the population of African and Asian regions will increase from 14 to $23 \%$. So, labour migration from these territories will grow and the European region will have a significant demand for labour force. To keep the population at the required level until 2050, European countries will need 47.9 million migrants, while Russia will need 25 million. To keep the number of able-bodied people it is needed even a larger number of migrants: 79 million people for EU countries and 35.8 million people for Russia (Miklovda, Pitiulych, 2013).

During the time of Ukraine's independence migration has a very significant place, especially external labour migration. However, the concept of migration and labour migration should be clearly distinguished. The term «labour migration» is defined as the movement of a person for the purpose of temporary employment accompanied by the crossing of the state border (external labour migration) or the borders of administrative and territorial units of Ukraine (internal labour migration) (Kapitan, 2012).

The Law of Ukraine «On Ratification of the European Convention on the Legal Status of Migrant Workers» specifies that the term «labor migrant» means a citizen of a Contracting Party State who was allowed by another Contracting Party to stay on its territory with the purpose of carrying out the paid work (Zakon Ukrainy «Pro ratyfikatsiiu Yevropeiskoi konventsii pro pravovyi status trudiashchykh-mihrantiv»», 2007). That is, employment is an obligatory condition of the labour migration. 
Table 1. Migration traffic in the regions of Ukraine (MihratsiinyirukhnaselenniaUkrainy, 2017)

\begin{tabular}{|c|c|c|c|c|c|c|c|}
\hline \multirow[b]{2}{*}{$\underset{\text { Unit }}{\text { Administrative }}$} & \multicolumn{3}{|c|}{ All migration flows } & \multicolumn{3}{|c|}{ All flows including Interstate migration } & \multirow{2}{*}{$\begin{array}{l}\text { Overall } \\
\text { migration } \\
\text { rate increase } \\
\text { reduction } \\
(-), \text { per } 10 \\
\text { 000 available } \\
\text { population }\end{array}$} \\
\hline & $\begin{array}{l}\text { Number } \\
\text { of } \\
\text { arrivals }\end{array}$ & $\begin{array}{l}\text { Number of } \\
\text { departures }\end{array}$ & $\begin{array}{c}\text { Migration } \\
\text { increase } \\
(-)\end{array}$ & $\begin{array}{l}\text { Number } \\
\text { of } \\
\text { arrivals }\end{array}$ & $\begin{array}{l}\text { Number of } \\
\text { departures }\end{array}$ & $\begin{array}{c}\text { Migration } \\
\text { increase } \\
(-)\end{array}$ & \\
\hline ARC & - & - & - & - & - & - & - \\
\hline Ukraine & 533278 & 519045 & 14233 & 30569 & 21409 & 9250 & 0,8 \\
\hline Vinnytsya & 27829 & 27143 & 683 & 755 & 298 & 457 & 0,4 \\
\hline Volyn & 16253 & 16134 & 119 & 414 & 272 & 142 & 0,1 \\
\hline Dnipropetrovsk & 37594 & 38945 & -1351 & 2126 & 2300 & -174 & $-0,4$ \\
\hline Donetsk & 16662 & 25900 & -9239 & 516 & 315 & 201 & $\ldots$ \\
\hline Zhytomyr & 19783 & 21063 & -1280 & 596 & 355 & 241 & $-1,0$ \\
\hline Transcarpathian & 6103 & 7754 & -1651 & 266 & 1519 & -1253 & $-1,3$ \\
\hline Zaporizhzhia & 17890 & 18687 & -797 & 1163 & 965 & 198 & $-0,5$ \\
\hline Ivano-Frankivsk & 18870 & 16972 & 1901 & 989 & 707 & 282 & 1,4 \\
\hline Kirovograd & 14898 & 15586 & -688 & 554 & 350 & 204 & $-0,7$ \\
\hline Luhansk & 5974 & 11608 & -5634 & 254 & 68 & 177 & $\ldots$ \\
\hline Lviv & 31499 & 30164 & 1335 & 1007 & 713 & 294 & 0,5 \\
\hline Mykolayivska & 14023 & 13817 & 206 & 799 & 541 & 258 & 0,2 \\
\hline Odessa & 25781 & 24795 & 986 & 3151 & 2126 & 1025 & 0,4 \\
\hline Poltava & 23735 & 22745 & 990 & 1020 & 328 & 692 & 0,7 \\
\hline Rivne & 19812 & 20594 & -782 & 332 & 346 & -14 & $-0,7$ \\
\hline Sumy & 18334 & 19308 & -974 & 568 & 496 & 72 & $-0,9$ \\
\hline Ternopil & 15263 & 15013 & 250 & 698 & 312 & 386 & 0,2 \\
\hline Kharkiv & 40549 & 35568 & 4981 & 5533 & 3291 & 2242 & 1,8 \\
\hline Kherson & 12646 & 12947 & -30 & 406 & 286 & 120 & $-0,3$ \\
\hline Khmelnitska & 22350 & 22524 & -174 & 481 & 252 & 229 & $-0,1$ \\
\hline Cherkasy & 18680 & 18868 & -188 & 777 & 359 & 418 & $-0,1$ \\
\hline Chernivtsi & 10548 & 9552 & 996 & 735 & 382 & 353 & 1,1 \\
\hline Chernihiv & 16538 & 16383 & 155 & 594 & 282 & 312 & 0,1 \\
\hline Kyiv & 46107 & 32645 & 13462 & 5620 & 4095 & 1525 & 4,6 \\
\hline
\end{tabular}

According to the State Statistics Committee 16 million people in Ukraine are active economically, but only $12,800,000$ work officially. It means that the problems in the pension system will arise first and foremost. Even today there are 15 pensioners per 10 Ukrainian workers. If the pace of migration remains at this level, the ratio will change from 8 to 15 . Analysts warn that due to the outflow of labour resources Ukraine loses about 40 billion UAH annually. In addition, the shortage of workers inhibits the development of some sectors of industry and agriculture and leads to the decline of regions and depression.

It should be noted that unemployment is a major factor driving labour migration on the territories of our research. The recession of the Ukrainian economy has led to the increase in unemployment among the population. And although the pace of recovery in economic activity shows a positive dynamics it has not yet succeeded in attaining the level of employment at least in the pre-crisis period (Nadtochii, 2015). The main reason for the rise of unemployment was the fall of the economy and the corresponding financial decline of the enterprises. Some companies have gone bankrupt, some have started to reduce their expenses and optimize the staff. Another factor was the increase of the minimum wage to $3,200 \mathrm{UAH}$ (in 2017). This forced the entrepreneurs who are not able to increase the payroll, transfer their employees to a part-time work or even to informal employment. The increase in the minimum wage has affected the activities of a small business with its simplified taxation system.

Unemployment has negative social and economic consequences for both the state and the population. The state loses incomes in the form of taxes, while increasing its expenses due to payments for unemployment. And in accordance with Okun's law, if the unemployment rate increases by more than $1 \%$ of the natural level, the country loses about 2-3\% of GDP. As for the population, the unemployment benefits are insignificant and it is rather difficult to live on them (Havrylets, 2014).

Another negative consequence of the growth unemployment is the increase in the large burden on working people. And it is constantly rising at the background of the demographic crisis in Ukraine. That is, the amount of social contributions due to which the budget of the Pension Fund is formed, is increasing. The majority of the unemployed in 
Ukraine are young people under 24 (Kapitan, 2012).

According to the State Statistics Service of Ukraine, unemployment in 2014 increased by $2 \%$ and has been growing steadily ever since. At the first half of 2016 the unemployment rate was $9.4 \%$. The situation is even more critical for young people: at the same period of 2016, the unemployment rate was $14.7 \%$. One of the reasons is the reluctance of young people to work in specialties and move to the rural areas, which affects the labour market of the agricultural sector. The worst situation with employment is observed for men at the age of 15-24 (25.6\%), whereas for women of the same group this indicator is $6 \%$ lower (Zapadniuk, 2011).

The analysis of the unemployment rate in the regions of Ukraine in January 2017 shows a significant disproportion in employment. Among the reasons we single out the following: 1) different social and economic level of development; 2) low wages; 3) military actions in the East of the country.

Fig.1 shows that the best employment situation is in Kharkiv, Kyiv, Odessa, Lviv, Dnipropetrovsk regions, and the worst one is in Luhansk, Donetsk, Volyn, Ternopil and Kirovograd regions. According to the estimates of the International Organization for Migration there were 915 thousand Ukrainians working abroad in 2017.

In general, $12 \%$ of our compatriots found work outside the country or were going to do it in the nearest time. The highest level of potential labour migrants is in the regions having been left by the majority of the able-bodied population: Luhansk, Donetsk, Volyn, Ternopil, Transcarpathian and Rivne regions.

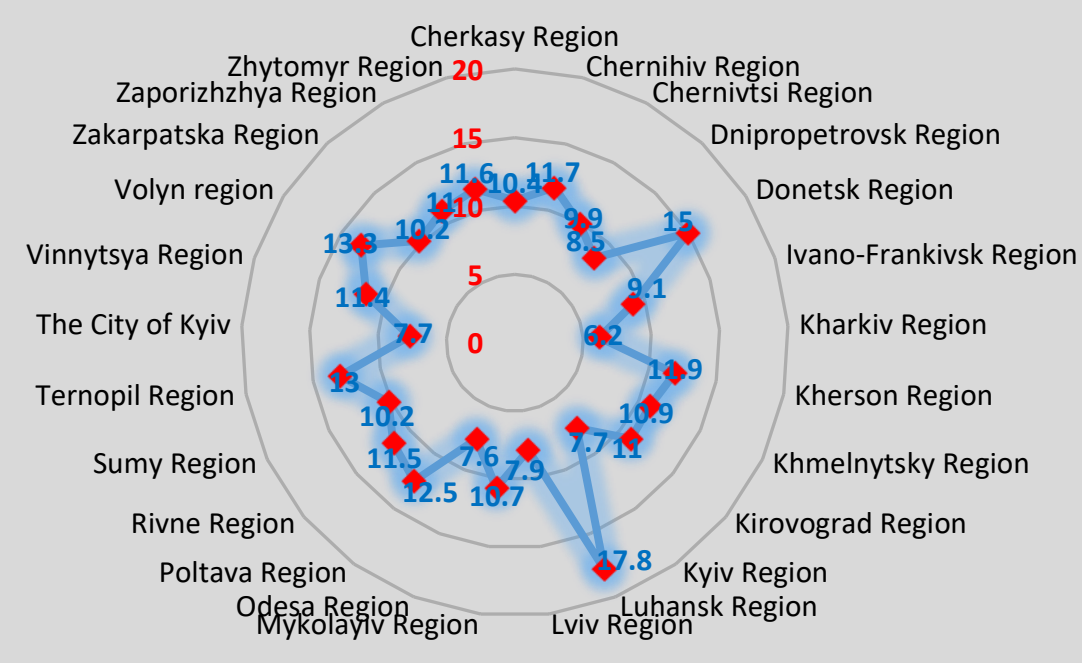

Fig. 1. Unemployment rate among the working-age population (according to ILO methodology) by the regions of Ukraine in the first quarter of 2018,\% (Demohrafichna ta sotsialna statystyka, 2017)

These important arguments prove the inevitability of the intensification of labor migration flows to the countries of the European Union, and the European vector of labor migration for the Ukrainians remains decisive not only today, but also in the long run.

The analysis of statistical data allowed us to single out the countries, which became the most covered by labor migration from Ukraine in 2017 (Fig. 2) - Poland, Russia, Italy, the Czech Republic and others.

According to a study by the International Labor Organization (IOM), the average monthly earnings of one labor migrant in January-November 2017 amounted to $\$ 722$, and the salary of one fulltime employee in Ukraine is approximately \$203. The average monthly salary in some countries of the world in 2017 is shown in Fig. 3 for comparison.

The analysis of statistical data made it possible to determine the dynamics of labor migration from Ukraine and to identify the countries of their deployment, namely: in 2008, the number of labor migrants from our country was 1.2 million people and according to the employment rating the countries chosen were Russia, Italy, Czech Republic, Poland and Hungary; in 2012, the number of labor migrants did not change (1.2 million), but the vectors of the countries chosen by the migrants changed, and they were Russia, Poland, Italy, Czech Republic, Spain; in 2017, compared with the previous years, the number of labor migrants increased to 1.3 million people and they settled in Poland, Russia, Italy, the Czech Republic, and the USA. 


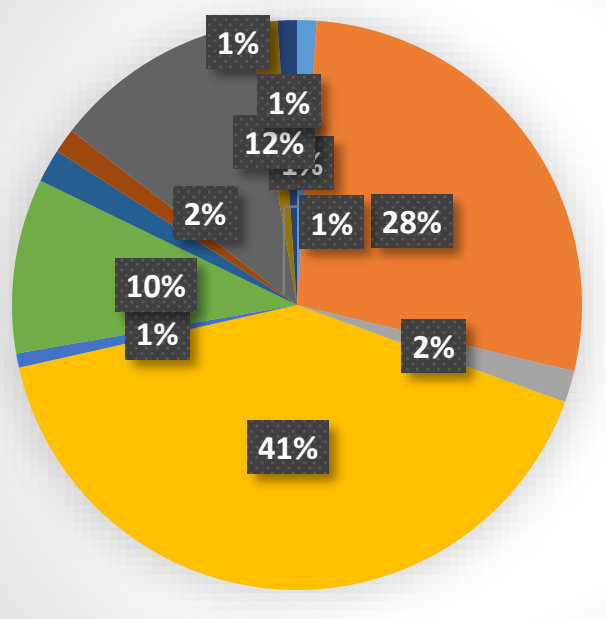

- Finland
Russia
Belorus
Poland
- Germany
- Czech Repablic
- USA
- Hungary
- Italy
- Portugal
- Israel

Fig. 2. Percentage of Ukrainian population migration for the purpose of employment in the period from 2015 to 2017 (Mihratsiinyi rukh naselennia Ukrainy, 2017)

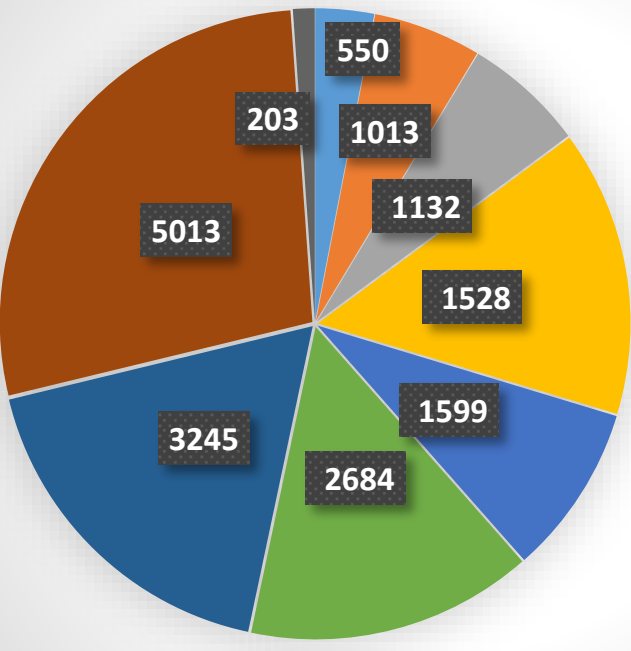

Russia
Poland
Czech Republic
Potugal
Greece
- Spain
- Israel
- USA
- Ukraine

Fig. 3. Average monthly salary in some countries in 2017 (USD\$ ) (Demohrafichna na sotsialna statystyka, 2017)

Somewhat different is the spatial pattern of the movement of labor migrants of Ukraine directly to the neighboring countries (Fig. 4). We observe a sharp increase in their number in the period from 2012 to 2017 in Poland (up to 10 million people), Hungary (up to 3 million people), Romania and Slovakia $(1,500,000$ people). The departure of Ukrainian citizens to Russia somewhat decreased, in particular, in 2013 their number was the largest and amounted to more than 6 million people. In the period of 2014-2016 due to military actions in eastern Ukraine their number decreased to 4 million people and only in 2017 it began to grow again and amounted to 5 million people. It should be noted that $60 \%$ of them are labor migrants.

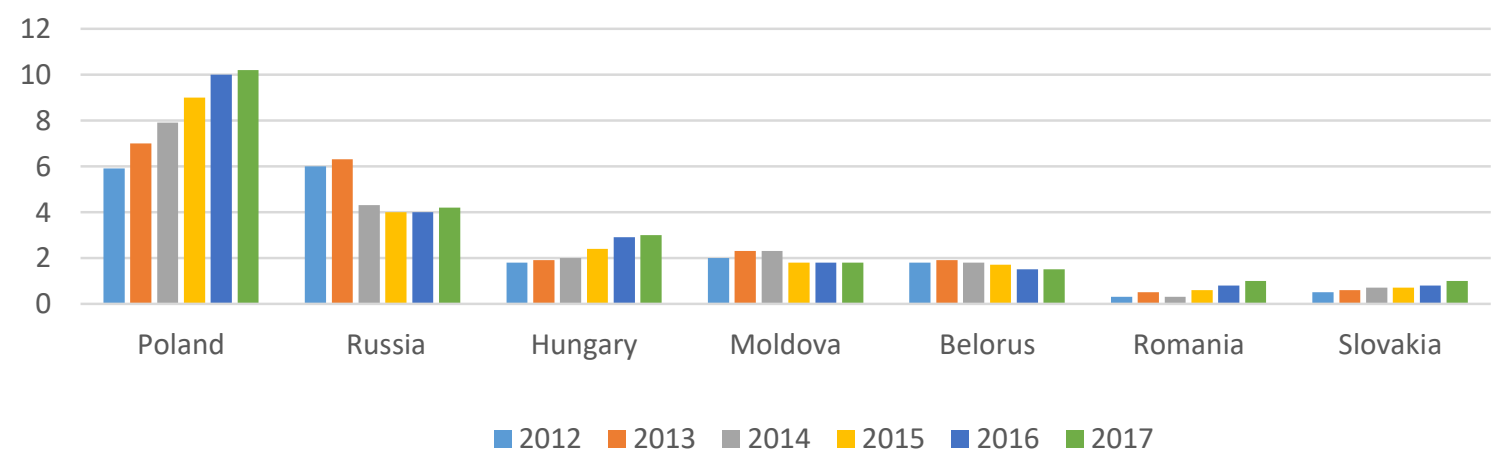

Fig. 4. Departure of Ukrainian citizens to the neighboring countries (millions of people) (Ekonomichna statystyka Ukrainy, 2017) 
For their part, the government claims that from 2.5 to 4 million people work abroad. At the end of last year, the volume of foreign currency earnings to
Ukraine from the «labour migrants» (zarobitchan) amounted to 9.4 billion US \$ (Fig. 5)

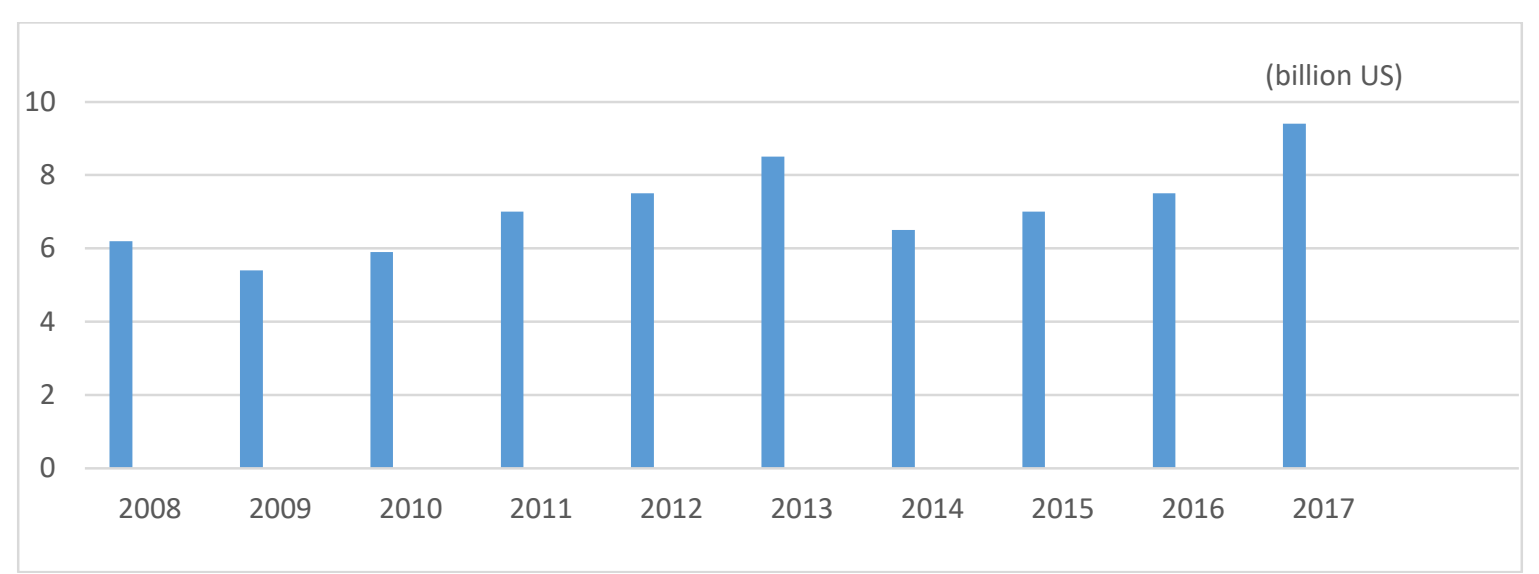

Fig. 5. Migrant Remittances (US billion dollars) (Statystyka, 2017)

The volume of remittances to Ukraine from abroad was:

- 2015 - 6959 billion dollars;

- 2016 - 7535 billion dollars;

- 2017 - 9490 billion dollars. (Statystyka, 2017).

Respectively, the TOP 10 countries that provided the largest cash inflows to Ukraine are
Poland, Russia, USA, Czech Republic, Italy, Germany, Israel, Great Britain, Cyprus, Greece.

At the same time, foreign direct investment was only 23 trillion US dollars. So, the labor migrants gave odds to all foreign investors combined.

For comparison, labor migrants from other countries replenished the budget of their countries as follows (Table 2).

Table 2. Capital inflows from the «post-Soviet countries» labor migrants (Ekonomichna statystyka, 2017)

\begin{tabular}{|l|c|}
\hline \multicolumn{1}{|c|}{ Name of country } & $\begin{array}{c}\text { Income from labour migrants in monetary } \\
\text { equivalent for 2017 } \\
\text { (billion dollars) }\end{array}$ \\
\hline Ukraine & 9,4 \\
\hline Uzbekistan & 3,9 \\
\hline Tajikistan & 2,5 \\
\hline Kyrgyzstan & 2,4 \\
Moldova & 1,2 \\
\hline Belarus & 1,0 \\
\hline Armenia & 1,0 \\
\hline
\end{tabular}

In the coming years, Ukraine will face the problem of labor shortages and will be forced to attract a large number of migrants from abroad. We consider that Vietnam, Belarus and even Russia can be among the countries to provide Ukraine with labor force.

Analyzing the situation that has developed in Ukraine at the regional level, we see that the Transcarpathian region, which borders directly on the four European countries, will remain in the risk zone of labor migrants. Its population, according to estimates, as of January 1, 2017 was 1, 25 million people

During 2016, its population decreased by 381 people. The decrease in the population of the region is due to the migration reduction of the population by 982 people. At the same time, natural growth remains to be positive due to the high birth rate of the Roma population (Holovne upravlinnia statystyky and Zakarpatskii oblasti, 2017) and is 601 people during a year. 
The vector of labor migrations from the Transcarpathian region is unequivocally directed in favor of the EU countries. This is due to a number of factors, namely:

- Ukraine receiving the status of an independent sovereign state;

- Ukraine's course on European integration;

- historical and ethnic component of the peoples on both sides of the borders;

- visa regime with the EU countries;

- the opportunity to get high wages, etc. (Havrylets, 2014).

During 2017 more than 6000 people left Transcarpathia. More than 400 Transcarpathians moved to Europe, the rest - to the CIS countries. Over 450 people left for the long term (over 1 month). Most of them are in Hungary, the Czech Republic, Germany, Slovakia and the USA (Holovne upravlinnia statystyky u Zakarpatskii oblasti, 2017). If in 2008 the number of those who departed was 2.2 times higher than those who arrived in the region, then in 2010 these figures were almost equal, however, there was no migration increase.

Since 2012, the trend towards an increase in the migration decline in the population within the framework of interstate migration has been observed again, and in 2016 the number of departures was almost 5.5 times higher than the number of arrivals to the Transcarpathian region.

Back in 2015, labor migration in the Transcarpathian region turned into a «mass phenomenon» and the number of people who went abroad increased by $30 \%$, and this trend continues nowadays. This is evidenced by the results of a survey of the «Rating» group sociologists. More than $55 \%$ of respondents in Transcarpathia reported that their relatives were permanently or temporarily working abroad. In the end, more than $35 \%$ of respondents in eight regions of Western Ukraine answered that some of their relatives had been working abroad for the last six months. In general, this figure is $28 \%$ in Ukraine. $53.3 \%$ of Ukrainians choose Poland as their country of employment.

This is primarily due to the economic situation and the devaluation of the hryvnia. In addition, the Russian ruble devalued, so labor migrants changed the vector of movement from Russia to Western European countries. It's worth mentioning that most of all only the residents of small towns and villages who purposefully go to work on low-skilled jobs are leaving.

The conducted sociological research has shown that the main recipient countries of labor migrants from Transcarpathia are the EU countries, and labor migration has a number of specific features (Miklovda, Pitiulych, 2013) (Table 3)

Table 3. Characteristics of the countries of departure of labor migrants from the Transcarpathian region by type of migration (Miklovda, Pitiulych 2013)

\begin{tabular}{|l|l|}
\hline \multicolumn{1}{|c|}{$\begin{array}{c}\text { Country of } \\
\text { departure }\end{array}$} & \multicolumn{1}{c|}{ Type of migration } \\
\hline Russia & Seasonal, mostly male, illegal \\
\hline Belarus & Seasonal, male \\
\hline Slovakia & Seasonal,transit, shuttle \\
\hline Hungary & Shuttle, transit \\
\hline Poland & Seasonal, female, agricultural \\
\hline Czech Republic & Male, partially transit \\
\hline Italy & Female, legal \\
\hline Portugal & Male and family \\
\hline Spain & Predominantly family \\
\hline Germany & Long-term migration, predominantly skilled workers \\
\hline
\end{tabular}

If the Ukrainians leave for work in the EU, then Romania is an exception among them. Despite the fact that the country has been a member of the EU since 2007, it remains one of the poorest countries with an average salary of $€ 565$ «net» per month. Therefore, the Romanian realities of labor migration are very similar to Ukrainian ones. It is predominantly characterized by the family type of migration and prevailing work in agriculture. According to the World Bank, from 3 to 5 million Romanians mostly young people live and work abroad, in Germany, Italy, Portugal, Spain and other EU countries. This should have been a problem for the country with the population of 19.5 million, but the government understands that labor migrants annually bring to the budget 4-5 billion dollars. The problem of the vacant places employment is planned to be filled by increasing the quota for foreign workers to 20 thousand, that is 5 thousand more in comparison with the last year.

If you compare the «eastern» and «western» vectors of labor migration from Transcarpathia, then they have the following features: 
- The «eastern» vector is characterized by lower wages and worse living conditions for migrant workers, prevalence of working professions, seasonal nature, as a rule, in construction or in agriculture;

- The «western» vector, on the contrary, means better living conditions for migrant workers, higher level of education, higher wages, and diversification of labor activities.

In fact, labor migration on the territory of research has become large-scale, included up to $30 \%$ of the working population, and remains an important factor in the employment of the population of the region.

Conclusions. As a result, nowadays western regions of Ukraine and the Transcarpathian region in particular, do not have a well-considered migration policy. The situation that has developed in the field of labor migration requires the government to take actions to regulate labor migration at the legislative level and the implementation of a whole range of measures, including:

- protection of the rights of labor migrants, legalization of their employment;

- development of special regional programs for stimulating self-employment of those migrants who returned from abroad after labor migration;

- assistance from public authorities in opening own businesses, small businesses and farm households of labor migrants who returned home;

- provide them with the opportunity to take refresher and retraining courses in one area or another and the like.

Thus, the analysis of the new labor migration trends of Ukraine requires strengthening of international cooperation with the member states of the European Union in creating favorable conditions for legalizing Ukrainian labor migrants, cooperation in the field of border control, facilitating reverse migration, and improving the socio-economic standard of living in Ukraine, because we estimate the risks of labor migration as alarming.

\section{References}

Zakon Ukrainy «Pro ratyfikatsiiu Yevropeiskoi konventsii pro pravovyi status trudiashchykhmihrantiv» № 75-V vid 16.03. 2007 r., 2007 [The Law of Ukraine «On Ratification of the European Convention on the Legal Status of Migrant Workers»]. Vidomosti Verkhovnoi Rady Ukrainy, Vyp 21 (in Ukrainian).
Demohrafichna ta sotsialna statystyka [Demographic for social statistics] Ofitsiinyi sait Derzhavnoi sluzhby statystyky Ukrainy Retrieved from http://www.ukrstat.gov.ua/operativ/oper_new.htm 1 (in Ukrainian).

Ekonomichna statystyka [Economichna statystyka]. Ofitsiinyi sait Derzhavnoi sluzhby statystyky Ukrainy. Retrieved from http://www.ukrstat.gov.ua/operativ/oper_new.htm 1 (in Ukrainian).

Havrylets O.V., 2014. Analiz sotsialno-ekonomichnykh peredumov mihratsii $\mathrm{v}$ Zakarpatskii oblasti [Analysis of the socio-economic conditions of migration in the Transcarpathian region]. Hlobalni ta natsionalni problemy ekonomiky, Vyp 2, 811-815 (in Ukrainian).

Holovne upravlinnia statystyky u Zakarpatskii oblasti. Statystychna informatsiia. [Statistical information]. Retrieved from http://www.uz.ukrstat.gov.ua/ (in Ukrainian).

Kapitan V., 2012. Trudova mihratsiia yak aspekt problemy zainiatosti $\mathrm{v}$ Ukraini [Labor migration as an aspect of the employment in Ukraine]. Efektyvnist derzhavnoho upravlinnia, Vyp. 32, $474-481$ (in Ukrainian).

Mihratsiinyi rukh naselennia Ukrainy u 2017 rotsi [Migration movement of the population in Ukraine in the 2017 ]. Retrieved from http://www.ukrstat.gov.ua/operativ/operativ2018/ ds/mr/mr_u/arh_mr2018 u.html (in Ukrainian).

Miklovda V.P., Pitiulych M.I., 2003. Rehionalni problemy rozvytku i vykorystannia trudovoho potentsialu [Regional problems of the development and exploit of the labor potential]. Rehionalna ekonomika. Vyp. 3, 244-245 (in Ukrainian).

Miklovda V.P., Pitiulych M.I., 2013. Trudova mihratsiia naselennia Zakarpattia $\mathrm{v}$ umovakh pohlyblennia yevrointehratsiinykh protsesiv [Labor migration of the population of Transcarpathia region in conditions of the deepening of European integration processes]. Sotsialno-ekonomichni problemy suchasnoho periodu Ukrainy. Vyp. 3(101), 324-331 (in Ukrainian).

Nadtochii A.O., 2015. Prychyny zovnishnoi trudovoi mihratsii ta otsinka yii naslidkiv dlia ekonomiky Ukrainy [Causes of the external labor migration and estimation of its consequences for the Ukrainian economy]. Teoriia ta praktyka derzhavnoho upravlinnia. Vyp.1 (48), 1-8 (in Ukrainian).

Statystyka [Statistics]. Статистика. Офіційний сайт Національного банку України http://www.prostobank.ua/spravochniki/banki/id/ $\underline{986}$ (in Ukrainian).

Zapadniuk S.O., 2011. Mihratsii naselennia Ukrainy: peredumovy, dynamika ta naslidky rozvytku [Migration of the population of Ukraine: preconditions, dynamics and development implications]. Kyiv (in Ukrainian). 